\title{
MEMERANGI TITIK JENUH KULIAH ONLINE DI MASA PANDEMI COVID 19
}

\author{
COMBATING SATURATION SPOT ONLINE DURING THE COVID PANDEMIC \\ 19
}

\section{INDINA SALSABILA}

\begin{abstract}
Program Studi Psikologi, Fakults kedokteran Universitas Lambung Mangkurat Jl.A.Yani km 36 Banjarbaru Kalimantan Selatan Kode Pos 70714, Indonesia Email :
\end{abstract} 2010914120016@mhs.ulm.ac.id No.Handphone :085651278026

\begin{abstract}
ABSTRAK
Wabah pandemi Covid-19 ini mengakibatkan setiap orang harus melakukan segala aktivitas secara online. Berbagai macam aktivitas yang pada mula nya dilaksanakan dengan melibatkan banyak orang harus di batasi atau dilaksanakan secara daring atau online. Terutama dalam pelaksaan perkuliahan yang harus dilaksanakan secara online. Hal ini dimaksudkan untuk mencegah penyebaran virus corona. Kuliah online ini lama kelamaan menyebabkan mahasiswa menemui suatu titik jenuh dikarenakan banyak hal yang menghambat proses perkuliahan secara online ini. Akibatnya banyak mahasiswa hanya mengikuti perkuliahan tanpa paham apa yang telah dipelajari sebelumnya. Hal ini tentu saja merupakan menjadi salah satu penghambat mahasiswa untuk dapat berkembang secara maksimal. Tujuan dari kajian ini adalah untuk mengetahui apa penyebab dari titik jenuh yang dirasakan mahasiswa pada kuliah online di masa pandemi Covid-19 ini dan bagaimana cara mengatasi titik jenuh tersebut. Dalam melakukan kajian ini penulis menggunakan metode studi pustaka terhadap berbagai kajian terhadulu yang pernah dilakukan. Hasil yang diperoleh dari penelitian ini adalah bahwa penyebab mahasiswa jenuh dengan kuliah online adalah tidak dapat berinteraksi secara langsung dalam perkuliahan dan tidak dapat mengenal secara langsung teman-teman baru. Cara mengatasi titik jenuh ini adalah dengan motivasi dari orang tua dan dukungan dari orang-orang sekitar.
\end{abstract}

Kata Kunci : titik jenuh, kuliah online, covid-19

\section{ABSTRACT}


The ferocity of the Covid-19 pandemic has resulted in everyone having to do all activities online. The various activities that were originally carried out involving many people must be limited or carried out online or online. Especially in the implementation of lectures that must be carried out online. This is intended to prevent the spread of the corona virus. This online lecture over time causes students to meet a saturation point due to many things that hinder the online lecture process. As a result, many students only attend lectures without understanding what they have previously learned. Of course, this is one of the obstacles for students to develop optimally. The purpose of this study is to find out what causes the saturation point felt by students in online lectures during the Covid-19 pandemic and how to overcome this saturation point. In conducting this study, the author uses the literature study method of various previous studies that have been carried out. The results obtained from this study are that the cause of students being bored with online lectures is that they cannot interact directly in lectures and can not get to know new friends directly. The way to overcome this saturation point is with motivation from parents and support from those around you.

Keywords: saturation point, online lecture, covid-19

\section{PENDAHULUAN}

Virus Covid-19 muncul sekitar awal tahun 2020 diduga berasal dari kota Wuhan China. Kemunculannya menggemparkan seluruh dunia. Awalnya negara Indonesia di klaim sebagai negara yang tidak mungkin terjangkit oleh virus Covid-19 ini, akan tetapi hal itu hanya hoax belaka. Awal kemunculan virus ini dimulai dengan 2 orang pertama yang terjangkit virus Covid19 di Indonesia. Semakin lama jumlah orang yang terjangkit virus Covid-19 semakin meningkat jumlah nya sehingga pemerintah menghimbau agar masyarakat tidak keluar dari rumah dan menerapkan sosial distancing . Pada akhirnya semua kegiatan diharuskan untuk dilaksanakan secara online. Tanpa terkecuali proses perkuliahan. Perkuliahan online dilakukan bertujuan untuk tercipta kualitas pembelajaran bagi peserta didik dalam masa pandemic [1].

Pada awalnya menyenangkan mendengar kabar bahwa kuliah akan dilaksanakan secara online karena banyak keuntungan yang di dapat dari pelaksanaan kuliah secara online ini. Salah satunya kuliah secara online ini sangat fleksibel dapat menghemat waktu karena tidak perlu pergi ke kampus dan tidak perlu bangun pagi-pagi sekali untuk bersiap pergi ke 
kampus. Akan tetapi lama-kelamaan kuliah online ini menjadi hal yang membosankan. Penyebabnya ada berbagai macam hal. Penyebabnya seperti lelah karena lelah menatap layar laptop setiap hari, tidak dapat berinteraksi secara langsung dengan dosen maupun teman-teman satu angkatan sehingga menyebabkan adanya rasa kebosanan.

Akhirnya mahasiswa mulai menemui titik jenuh dalam menghadapi kuliah secara online ini. Kejenuhan ini mengakibatkan mahasiswa menjadi kurang maksimal dalam menyerap ilmu-ilmu yang disampaikan oleh dosen sehingga mengikuti perkuliahan hanya sebagai sebuah formalitas tanpa memahami apa materi yang telah disampaikan. Hal ini tidak dapat terus di biarkan, karena walaupun kuliah online sebisa mungkin mahasiswa harus tetap fokus dan memperhatikan materi yang sedang disampaikan oleh dosen.

Tujuan dari penulisan kajian ini adalah untuk mengetahui penyebab kejenuhan mahasiswa terhadap kuliah online dan untuk menemukan solusi yang efektif agar mahasiswa dapat mengatasi rasa jenuh nya terhadap kuliah online.

\section{METODE PENELITIAN}

Penelitian ini adalah penelitian yang menggunakan kajian literatur atau metode studi pustaka. Metode studi kasus adalah sebuah metode penelitian dengan menggunakan beberapa jurnal yang diterbitkan di media internet dan metode ini juga menggunakan beberapa sumber pustaka dari media elektronik. Penulis melakukan kajian dengan memperbanyak informasi, mencari hubungan ke berbagai sumber, membandingkan dan menemukan hasil atas dasar data sebenarnya. Dalam penulisan ini, penulis melakukan kajian pustaka terhadap penyebab mahasiswa menjadi jenuh terhadap kuliah onlien. Sumber pustaka dalam penulisan ini menggunakan pemikiran yang terdapat dalam jurnal-jurnal yang di teliti secara ilmiah yang di terbitkan oleh para dosen.

Terlebih dahulu penulis memaparkan tentang pengertian titik jenuh secara umum. Setelah memaparkan secara umum penulis melanjutkan titik jenuh yang di alami mahasiswa pada masa pandemi covid-19 ini yaitu jenuh terhadap kuliah online. Selanjutnya penyebab kuliah online dapat menyebabkan jenuh dan bagaimana cara coping stress mahasiswa untuk mengatasi jenuh terhadap kuliah online. 
Dalam artikel ini penulis, menuliskan dan memaparkan beberapa kalimat yang berasal dari pemikiran penulis sendiri. Seperti yang dikatakan oleh Ersis Writing Theory (EWT): "Tulislah apa yang ada di pikiran bukan apa yang akan ditulis" [2].

\section{HASIL \& PEMBAHASAN}

Titik jenuh adalah suatu masa dimana seorang individu merasa bosan dengan aktivitas ataupun kegiatan yang dilakukkan. Titik jenuh bisa mendekati yang namanya stress. Marks, Murray \& Evans (2002) menjelaskan bahwa stres merupakan suatu keadaan ketika individu berada dalam situasi yang penuh tekanan atau ketika individu merasa tidak sanggup mengatasi tuntutan yang dihadapinya (dalam Fadillah, 2013) [3]. Tekanan yang dimaksud muncul dari berbagai macam hal, misal nya karena tuntutan perekonomian, pendidikan, politik, dll. Apalagi pada tahun 2020 ini muncul covid-19 yang mengakibatkan semua kegiatan harus dibatasi dengan mengikuti protokol kesehatan berupa menjaga jarak, mencuci tangan, dan memakai masker serta menjauhi kerumunan.

Pandemi covid-19 ini membuat orang-orang takut untuk beraktifitas di luar rumah akibat takut tertular oleh virus corona. Virus corona ini menyerang siapa pun tak kenal anak kecil, remaja, dewasa atau orang tua. Berbagai macam aktivitas yang pada mula nya dilaksanakan dengan melibatkan banyak orang harus di batasi atau dilaksanakan secara daring atau online. Hal ini dimaksudkan untuk mencegah penyebaran virus corona.

Dampak dari Covid-19 ini telah mempengaruhi semua aspek kehidupan, tak terkecuali dunia pendidikan. Pendidikan merupakan suatu hal yang sangat penting. Pendidikan diperlukan untuk sebagai sebuah pedoman dan pegangan hidup untuk menghadapi masa yang akan datang [4]. Jika pendidikan terganggu maka masa depan Indonesia juga akan terancam. Salah satu proses pendidikan yang terganggu akibat pandemi Covid-19 ini adalah proses perkuliahan. Mahasiswa harus mengubah banyak segisegi kehidupan, khususnya hal yang menyangkut perkuliahan, karena pandemi Covid-19 [5]. Proses belajar mengajar dan perkuliahan mau tidak mau harus dilaksanakan secara online. Kuliah online adalah proses pembelajaran yang memanfaatkan keunggulan komputer sebagai media perantara pengajar dengan mahasiswa agar mudah untuk berkomunikasi [6]. 
Lulusan SMA, MA tahun 2020 yang awalnya berharap akan bertemu dengan dunia perkuliahan yang asik bisa bertemu dengan teman baru tidak harus memakai seragam lagi, semua harapan itu sirna dengan adanya kuliah online. Awalnya memang terasa menyenangkan mengikuti kuliah secara online ini karena dapat menghemat waktu. Lama-kelamaan mahasiswa mulai merasakan titik jenuh karena setiap hari hanya memandang layar laptop dan hanya dapat mengenal teman secara virtual tanpa dapat berkenalan dan bersosialisasi secara langsung. Pada dasarnya manusia itu adalah makhluk sosial yang perlu berinteraksi dengan makhluk lain. Interaksi sosial merupakan hubungan sosial yang dinamis untuk menjalin hubungan sosial, yaitu hubungan sosial antara individu per individu, antara kelompok-kelompok manusia, maupun antara orang perorangan dengan kelompokkelompok manusia [7]. Contoh bentuk interaksi antar individu adalah persahabatan [8].

Kuliah online ini kurang efektif karena agak sulit untuk melatih fokus agar benar-benar memperhatikan materi yang diberikan oleh dosen karna sering terdistract dengan hal-hal lain. Akhirnya menyebabkan mahasiswa hanya mengikuti perkuliahan tanpa paham apa yang telah dipelajari sebelumnya. Hal ini tentu saja menjadi salah satu penghambat mahasiswa untuk dapat berkembang secara maksimal dan menurunkan semangat mahasiswa untuk belajar. Kuliah online ini juga menghambat mahasiswa baru untuk menyesuaikan diri dengan dunia perkuliahan yang sebenarnya. Belum lagi masalah kuota internet yang terbatas dan koneksi internet yang dapat menghambat proses kuliah online karena bisa saja sewaktu-waktu penjelasan dosen terputus akibat koneksi internet yang jelek sehingga menyebabkan mahasiswa tertinggal materi perkuliahan, bahkan masalah koneksi internet ini bisa saja hanya dijadikan sebuah alasan bagi mahasiswa yang malas atau kurang memiliki motivasi untuk belajar agar bisa mematikan kamera saat perkuliahan dan mengerjakan aktivitas yang lain.

Kuliah online ini pula mengakibatkan sulitnya untuk mengerjakan tugas kelompok, banyak diantara nya yang ketika tugas kelompok hanya memberikan persetujuan ketika berdiskusi tanpa memberikan saran apapun atau hanya menumpang nama saja tanpa berkontribusi apapun. Penyebab lain yang membuat mahasiswa jenuh dengan kuliah online adalah tugas yang lebih banyak 
dibandingkan dengan kuliah offline. Awalnya mahasiswa mengira kuliah online ini akan lebih mudah karena dapat menghemat waktu, akan tetapi kenyataan nya kuliah online ini menyebabkan lebih banyak tugas daripada kuliah offline.

Melihat dari sikap mahasiswa yang jenuh dengan kuliah online ini maka dapat disimpulkan kuliah online ini kurang berhasil. Keberhasilah suatu pembelajaran ditentukan apabila semua komponen dalam belajar dapat berinteraksi dan saling menunjang satu sama lain. Makmun (2007) mengemukakan ada tiga komponen yang penting dalam pembelajaran, yaitu (1) mahasiswa meningkatkan kemampuan akademik seoptimal mungkin melalui pembelajaran, (2) pengajar (dosen/guru) selalu menciptakan situasi yang tepat untuk belajar, sehingga memungkinkan untuk terjadinya pembelajaran, dan (3) tujuan, yaitu sesuatu yang diharapkan setelah pembelajaran (dalam Rahman et al., 2019) [9].

Berbeda dengan mahasiswa yang memiliki motivasi belajar yang tinggi, self efficacy, dan coping strees yang baik, maka ia dapat menyesuaikan diri dengan baik di dunia perkuliahan sehingga dapat mengesampingkan rasa jenuh tersebut. Self efficacy adalah keyakinan seseorang terhadap apa yang dia miliki dan coping strees adalah suatu upaya yang dilakukan seseorang untuk melakukan tuntutantuntutan yang sedang di hadapinya[4]. Mahasiswa yang memiliki self efficacy dan coping stress yang baik maka ia dapat dengan yakin dan baik mengatasi stress yang di alaminya sehingga dapat menyelesaikan berbagai tugas di perguruan tinggi. Dengan keyakinan tersebut juga maka seorang mahasiswa dapat mengatasi berbagai kendala yang datang menghampiri selama menjalani pendidikan di perguruan tinggi. Struthers, Perry dan Menec (2000) meneliti tentang hubungan antara stres akademik. Hasil penelitiannya menunjukkan bahwa perilaku coping mahasiswa (berfokus pada masalah dan emosi) mempengaruhi manajemen strees mahasiswa, dan ditemukan pula bahwa terdapat hubungan coping dan motivasi belajar, kemudian motivasi belajar dan stress akademik [10].

Ada berbagai macam faktor yang dapat mendukung mahasiswa agar dapat menyesuaikan diri dengan baik di perguruan tinggi di masa pandemi Covid-19 ini. Salah satunya adalah adanya motivasi. Kenyataanya tidak semua mahasiswa memiliki motivasi yang tinggi dalam menjalani pendidikan di perguruan tinggi 
apalagi dengan adanya keharusan beradaptasi kuliah secara online ini semakin membuat mahasiswa yang kurang motivasi berprestasi nya semakin malas untuk belajar. Motivasi terdiri atas dua macam yaitu motivasi instrinsik dan motivasi ekstrinsik. Chu dan Choi (2005) motivasi instrinsik adalah motivasi yang berasal dari dorongan dalam diri individu, sedangkan motivasi ekstrinsik adalah motivasi yang dihasilkan dari salah satu baik posistif atau negatif kemungkinan yang berasal dari luar diri individu (dalam Rachmah et al., 2015) [11]. Meclelland (1987). Motivasi berprestasi adalah suatu keinginan atau dorongan yang dimiliki seseorang untuk mencapai suatu kesuksesan atau keunggulan (dalam Mayangsari, 2016)[12]. Motivatisi instrinsik berupa keinginan dari dalam diri sendiri, seperti keinginan untuk lulus cumlaude, agar keinginan itu tercapai maka harus di wujudkan dengan giat belajar. Motivasi ekstrinsik berupa keinginan yang yang dipengaruhi oleh lingkungan seperti dukungan dari orang tua. Menurut Gunarsa (2003) menyatakan bahwa dorongan berprestasi yang berhubungan erat dengan aspek kepribadian harus dibina sejak kecil (dalam Mayangsari, 2016)[12]. Artinya didikan orang tua sejak masih kecil sangat mempengaruhi terhadap munculnya dorongan untuk mencapai suatu kesuksesan. Orang tua merupakan guru pertama sebelum guru di sekolah maupun dalam perkuliahan yang mendidik seorang anak. Dukungan orang tua berupa memberikan fasilitas belajar yang memadai ataupun memberikan bimbingan sekaligus motivasi. Motivasi untuk berprestasi juga bisa dipengaruhi oleh dukungan sosial orang-orang terdekat. Gottlieb (1983). dukungan sosial bisa didapatkan dari orang-orang terdekat yang akrab dengan subjek (dalam Amalia et al., 2020) [13]. Misalkan dukungan dari temanteman terdekat. Sebagai mahasiswa harus pintar dalam memilih pergaulan karena pergaulan sangat menentukan seorang mahasiswa dalam perkuliahan. Jika masuk ke dalam pergaulan yang positif maka pasti aura positif itu juga akan menular kepada diri sendiri begitu pun sebaliknya.

Ubah pola pikir agar lebih menikmati dengan adanya kuliah online selama pandemi Covid-19. Mengubah pola pikir sendiri pasti akan mempengaruhi mindset diri terhadap kuliah online, yang awalnya menganggap bahwa kuliah online itu membosankan menjadi lebih menikmati dengan kuliah online. Walaupun kuliah online tetap lakukan kegiatan layaknya kuliah offline, seperti memakai pakaian rapi dan lengkap dan selalu mencatat poin-poin 
penting yang disampaikan dosen ketika perkuliahan. Mencatat juga bisa menjadi aktivitas tambahan untuk menghindari jenuh pada saat perkuliahan, mencatat memiliki manfaat akan membuat menjadi lebih paham dengan materi walaupun sedang dalam kuliah online. Hal yang terpenting adalah dikarenakan pada saat kuliah online ini kebanyakan dosen memilih untuk memberi banyak tugas maka hindarilah menundanunda mengerjakan tugas atau mengerjakan ketika deadline sudah dekat yang akhirnya akan menyebabkan hasil yang kurang maksimal.

\section{SIMPULAN}

Pandemi covid-19 ini membuat orang-orang takut untuk beraktifitas di luar rumah akibat takut tertular oleh virus corona. Berbagai macam aktivitas yang pada mula nya dilaksanakan dengan melibatkan banyak orang harus di batasi atau dilaksanakan secara daring atau online. Hal ini dimaksudkan untuk mencegah penyebaran virus corona.

Kuliah online ini kurang efektif karena agak sulit untuk melatih fokus agar benar-benar memperhatikan materi yang diberikan oleh dosen karna sering terdistract dengan hal-hal lain.Kuliah online ini juga menghambat mahasiswa baru untuk menyesuaikan diri dengan dunia perkuliahan yang sebenarnya. Awalnya mahasiswa mengira kuliah online ini akan lebih mudah karena dapat menghemat waktu, akan tetapi kenyataan nya kuliah online ini menyebabkan lebih banyak tugas daripada kuliah offline. Hal ini mnyebabkan mahasiswa menjadi jenuh untuk menjalani kuliah secara daring atau kuliah online.

Cara agar mahasiswa dapat mengatasi rasa jenuh di perguruan tinggi selama pandemi Covid-19 ini adalah adanya motivasi. Motivasi terdiri atas dua macam yaitu motivasi instrinsik dan motivasi ekstrinsik. Motivasi instrinsik adalah motivasi yang berasal dari dalam diri dan motivasi ekstrinsik adalah motivasi yang berasal dari luar. Selain motivasi cara untuk mengatasi rasa jenuh dalam menjalani perkuliahan secara online adalah mengubah pola pikir diri sendiri bahwa kuliah online itu membosankan, tetap melakukan kegiatan seperti kuliah offline seperti memakai pakaian rapi dan lengkap, selalu mencatat materi yang disampaikan oleh dosen agar menjadi sebuah aktivitas tambahan dan dapat memahami materi secara mendalam, serta yang terpenting hindari untuk menunda-nunda dalam menyelesaikan tugas.

\section{DAFTAR PUSTAKA}


[1] Ningsih, D. M. R. (2020). PENGARUH METODE KULIAH ONLINE TERHADAP TINGKAT PEMAHAMAN MATERI KULIAH HUKUM INVESTASI PADA MAHASISWA UNIVERSITAS TEKNOLOGI INDONESIA. Jurnal

Pendidikan, 21(2), 104-110.

[2] WARMANSYAH ABBAS, E. R. S. I. S. (2020). Menulis di Era Covid-19: Memanage Trauma Psikologis Menghindari Psikosomatis. Menulis di Era Covid-19: Memanage Trauma Psikologis Menghindari Psikosomatis.

[3] Fadillah, A. E. R. (2013). Stres dan Motivasi Belajar pada Mahasiswa Psikologi Universitas Mulawarman yang Sedang Menyusun Skrispi. Psikoborneo, 1(3).

[4] Amini, M., Mayangsari, M. D., \& Zwagery, R. V. (2020). Hubungan antara Kemandirian Belajar dengan Komitmen Tugas pada Mahasiswa Program Studi Psikologi. Jurnal Kognisia: Jurnal Mahasiswa Psikologi Online, 2(2), 149-152.

[5] Abbas, E. W., \& Erlyani, N. (2020). Menulis di Kala Badai Covid-19.

[6] Riadi, S., Normelani, E. N., Efendi, M., Safitri, I., \& Tsabita, G. F. I. (2020). Persepsi Mahasiswa Prodi S1 Geografi FISIP ULM Terhadap Kuliah Online Di
Masa Pandemi Covid-19. PADARINGAN (Jurnal Pendidikan Sosiologi Antropologi), 2(2), 219-227.

[7] Aridarmaputri, G. S., Akbar, S. N., \& Yuniarrahmah, E. (2016). Pengaruh jejaring sosial terhadap kebutuhan afiliasi remaja di program Studi Psikologi Fakultas Kedokteran Universitas Lambung Mangkurat. Jurnal Ecopsy, 3(1).

[8] Putri, L. A., Anward, H. H., \& Zwagery, R. V. (2020). PERBEDAAN KUALITAS PERSAHABATAN DITINJAU DARI GAYA KELEKATAN PADA MAHASISWA PSIKOLOGI FAKULTAS KEDOKTERAN ULM. Kognisia prodi Psikologi FK ULM, 1(1), 23-28.

[9] Rahman, A. M., Mutiani, M., \& Putra, M. A. H. (2019). Pengaruh kompetensi pedagogik2 dosen terhadap motivasi belajar mahasiswa pendidikan IPS. Jurnal Darussalam: Jurnal Pendidikan, Komunikasi dan Pemikiran Hukum Islam, 10(2), 375-387.

[10] Rachmah, D. N. (2016). Self Efficacy, Coping Stress dan Prestasi Akademik Mahasiswa Program Studi Psikologi Fakultas Kedokteran Universitas Lambung Mangkurat. Jurnal Ecopsy, 1(1). 
[11] Rachmah, D. N., Mayangsari, M. D., \& Akbar, S. N. (2015). Motivasi belajar sebagai mediator hubungan kecerdasan adversitas dan prokrastinasi akademik pada mahasiswa yang aktif berorganisasi. Jurnal Cakrawala Pendidikan, 34(2).

[12] Mayangsari, M. D. (2016). Motivasi Berprestasi Mahasiswa Ditinjau dari Penerimaan Orangtua. Jurnal Ecopsy, 1(1).

[13 ] Amalia, D., Rachmah, D. N., \& Mayangsari, M. D. (2020). PERBEDAAN MOTIVASI BERPRESTASI PADA SANTRI PONDOK PESANTREN DAN PESERTA DIDIK SEKOLAH UMUM DI MARTAPURA. Kognisia prodi Psikologi FK ULM, 1(2), 38-46. 